\title{
Justice, Reciprocity and the Internalisation of Punishment in Victims of Crime
}

\author{
John S. Callender (iD
}

Received: 4 November 2017 / Accepted: 19 April 2018 /Published online: 2 May 2018

(C) The Author(s) 2018

\begin{abstract}
This paper is published as part of special issue on the theme of 'justice without retribution'. Any attempt to consider how justice may be achieved without retribution has to begin with a consideration of what we mean by justice. The most powerful pleas for justice usually come from those who feel that they have been harmed by the wrongful acts of others. This paper will explore this intuition about justice and will argue that it arises from the central importance of reciprocity, in the form of equity, balance and fairness, in human relationships. This is expressed in our image of justice, one of whose core symbols is a set of scales. I will use a clinical case to illustrate what can happen when criminal harm is not followed by any form of restitution. In this case, the punitive impulse was internalised in the victim and turned against herself in the form of deliberate self harm and, ultimately, death by suicide. I will argue that human relationships largely consist of reciprocal acts of good or harm and that we constantly strive for a balanced reciprocity in our relationships with others. This theme has been played out throughout human history in personal relationships, social customs, legal systems, religion and culture. It is also seen in higher primates. When someone is a victim of wrongful harm, there is a need to take measures to restore the balance which has been lost. I will attempt to draw a distinction between retributivism as the term is usually understood and the application of
\end{abstract}

J. S. Callender $(\bowtie)$

Department of Mental Health, Royal Cornhill Hospital, University of Aberdeen, Aberdeen AB25 7ZH, UK

e-mail: jscall@ doctors.org.uk the principle of reciprocity in criminal justice. This distinction is one that has found expression in what has become known as 'restorative justice' as opposed to conventional justice. There are two cardinal features of restorative justice in this context. The first is that it brings offender and victim into a relationship with the aim of repairing the harm that has been caused. The second is that it gives the offender the opportunity to give something back to his victim. I will conclude that our responses to criminal wrong-doing should be based on restorative principles and that punishment can sometimes be part of the process by which moral harm is made good.

Keywords Justice $\cdot$ Punishment $\cdot$ Reciprocity Internalisation $\cdot$ Suicide $\cdot$ Victim

\section{Introduction}

The traditional rationale for punishment under the law is that of retribution. Retributive punishment is based on three core principles. The first is that of desert i.e. that people who commit wrongful acts, especially serious crimes, deserve to suffer a proportionate punishment. Second, there is moral value to this punishment that does not depend on the achievement of any social benefit or other positive outcome. The third principle is that it is not morally permissible to punish the innocent or to inflict disproportionally severe punishments on the guilty [1]. 
One argument that is said to support retributivism is that there is a widely-held intuition that it is right and proper to punish wrong-doers even if this achieves no good purpose.

The main competing theories of punishment are those that fall under the headings of consequentialism or utilitarianism. In these theories, punishment has the explicit purpose of achieving social goods such as deterrence and incapacitation of offenders.

These theories run up against the third principle underpinning retribution. The intuitions that it is unjust to punish the innocent or to inflict disproportionately harsh punishments on offenders are held as widely as the intuition that offenders should be punished. A strict consequentialist view would be that punishment should be set at a level that achieves the desired aim (e.g. incapacitation) even if this is disproportionate to the crime or even that punishment of an innocent member of an offender's family or community would be justified if this served the purpose of deterrence.

A necessary start to our deliberations is to work out what we mean by justice. In the standard image of justice held by most people, there are three main features. The first is her blindfold, symbolising impartiality. In this paper, I'll focus on the other two defining symbols, the sword and the set of scales. The sword symbolises punishment and the scales represent the belief that punishment should be proportionate to the crime. I will extend the latter idea by arguing that a criminal act leads to a loss of balance or equilibrium in both the victim and the community and that restoration of this lost balance should be one role of the criminal justice system.

What is the source of our intuitions about punishment? I'll argue that reciprocity lies at the heart of human relationships. These are largely constituted by reciprocal acts of benefit or harm. We aim constantly for a balance between entitlement and obligation. If an act of serious harm is perpetrated this balance is disturbed and there is a need to restore equilibrium. Punishment may form part of this but is not always either necessary or sufficient.

The principle of restoring balance precludes disproportionate punishment or punishment of the innocent. Punishment of these types would create new imbalances which would require to be corrected in turn.

Why would the principle of reciprocity provide a moral justification for the enactment legal punishment and other measures? The main one is that the victim has been harmed by the crime and there is an obligation on the offender and the legal system to make good this harm as far as this is achievable. This harm can be both material and psychological. Legal proceedings can play an important role in helping victims of crime to recover from psychological harm. If the demands of reciprocity are not met, the victim may be left with feelings of anger, self-blame, helplessness, dread and loss of trust in her fellow human beings and society at large. At worst, this may result in depression, self-harm and suicide.

One approach to criminality that has an explicit focus on the needs of victims is restorative justice. There are important differences between this approach and retribution as it is currently enacted in most jurisdictions. The first is that reciprocal actions take place in the context of human relationships and serve the purpose of regulating these relationships. When a wrongful act is committed, the obligations owed by an offender to his victim have been violated. In restorative procedures, an attempt is made to mitigate this harm by bringing offender and victim together, with the aim of achieving some form of reconciliation. In contrast, conventional punishment under the law is taken over by the criminal justice system and the relationship between offender and victim plays no role. Second, reciprocal relationships entail an exchange of benefits, engaged in voluntarily by both parties. In restorative justice, the offender is given the opportunity to give something back to his victim. This might include explanation, apology, remorse and a commitment to personal change. Conventional criminal punishment comprises the infliction of harm and/or the withdrawal of benefits from an unwilling party.

I will conclude that restorative justice introduces the principles and practice of balanced reciprocity into the criminal justice system and will discuss research that demonstrates that this produces outcomes that are superior for victim, offender and society.

\section{Clinical Case}

I became involved with this young woman after her death when I was asked to prepare a report for a formal investigation, known in Scotland as a Fatal Accident Inquiry. I'll call her Susan Smith, although this was not her real name. Other facts have been changed in order to preserve anonymity, but these changes are not relevant to the conclusions that I attempt to draw.

Susan Smith was referred to mental health services at age 15 because of unmanageable behavior. Her problems included running away from home, frequent 
arguments with her parents and self-cutting. She exhibited rapid changes in mood and behavior.

Her problems escalated to the point at which she was also referred to social services and eventually sent to a residential facility for disturbed adolescents. There were concerns about high risk sexual activity and abuse of alcohol and drugs. She was verbally abusive and violent towards members of staff.

There were no prior problems. Her school records through primary and secondary schools indicated perfect attendance and no antisocial behavior until the onset of her difficulties.

Several months after being referred to psychiatric services, she revealed that, just prior to the onset of her problems, she had been raped whilst walking by a riverbank on her way home. She was attacked by two male strangers.

She continued to engage in acts of self-harm such as overdosing and self-strangulation. There were then two suicide attempts by fire-setting. The second of these occurred in the apartment in which Susan was living. She had made careful preparations for what she did. There was a real risk that the fire could have taken hold and caused serious damage and risk to other people.

She was charged with willful fire setting and was remanded in custody. At trial, she was sentenced to two years' imprisonment. Following this, she continued to cut herself and made repeated suicide attempts.

She wrote of how the rape had destroyed her body and her life. She said that she hated her body and that this was the reason that she cut herself. She wrote that she was depressed, that she had locked her emotions up inside and that she was exploding. Her self-harm culminated in her hanging herself six months into her period of imprisonment. She was two months short of her twentieth birthday.

It is important to emphasize that this young woman is entirely typical of incarcerated female offenders. Many studies attest to the high prevalence of traumatization and abuse in offenders. One study of female juvenile offenders found that only $12 \%$ had no history of traumatization or abuse [2].

It is well recognized that rape can cause severe and persisting psychiatric problems. Clements et al. [3] described a range of symptoms that can follow rape in adolescents. These symptoms fall into six groups; 1 . Altered affect regulation such as depression, chronic suicidal thoughts and anger control; 2. Altered consciousness such as flashbacks; 3 . Altered self- perception such as helplessness, shame, guilt and selfblame; 4. Altered relationships with others such as persistent distrust and withdrawal and failure to protect oneself; 5. Altered systems of meaning such as hopelessness and despair and 6. Somatization.

The response of the victim is often bewilderment, confusion and numbness. A poor outcome is associated with suicide attempts, substance misuse and negative self-assessment.

Post-traumatic stress disorder is very common in the aftermath of rape. One study in France found that $81 \%$ of rape victims suffered PTSD at one month following rape, $70 \%$ after three months and $65 \%$ six months later. Other symptoms such as fear, anger, anxiety, depression, guilt and self-blame are also common. The outcome following rape is generally worsened if the rape is accompanied by violence, perceived danger to life and physical injury [4].

In the case of adolescent rape, this is sometimes followed by high risk sexual behavior e.g. having sex with multiple partners, no use of contraception and early pregnancy. This may sometimes be an attempt on the part of the victim to gain control of her sexual life. Unfortunately, the effect is often that she is re-traumatized.

Another common response is anger and aggression directed against others. This can arise for several reasons.

One consequence of traumatization is that people develop a chronic 'fight or flight' response. This is a physiological response to threat and prepares the person for a sudden burst of activity, either to fight off the threat or to flee from it. This creates symptoms such as anxiety, tension, irritability, increased startle response and insomnia.

The victim is often left feeling very angry at those who have harmed her. This anger can be displaced on to others. The trauma victim who has flashbacks may sometimes feel that she is back in the traumatizing situation and will lash out at people who, she believes, are causing her serious harm.

Deliberate self-harm is common in the aftermath of sexual abuse and sexual assault. This can serve various functions. These include expressing pain when the victim feels she has no other way of doing this. A second reason for self-harm is that sexual assault can result in a sense that the body is spoiled or contaminated. This results in self-hatred. Self-harm then becomes an expression of anger against one's own body.

Whenever she was questioned about the rape, Susan seems usually to have said that she did not wish to discuss 
it and the matter was then dropped. This is commonly found in victims of rape. Reasons for non-disclosure include fear that the victim will be disbelieved or blamed. Recall of a traumatic event can be painful for the victim. Another reason may be the sense of shame and stigmatization that often accompanies rape.

Research studies in the USA have revealed that only 16-39\% of rape victims report the crime to the police. Reasons for non-disclosure to the police include aversion to the whole prospect of forensic examination and, again, a fear that the victim will be disbelieved [5].

Alcohol abuse is often found in the aftermath of traumatic events such as rape. This can be a way of dealing with hyperarousal symptoms such as anxiety, irritability and insomnia. Although it can help in this way, it often creates new problems by increasing the risk that the victim will be exposed to further traumatisation. Alcohol can lead to a weakening of inhibitions and increases the risks of suicide attempts and aggression in response to the kinds of negative feelings that can result from traumatization.

The next point illustrated by this case is what is sometimes called re-traumatization, and this is one that I wish to emphasize in this paper. One would intuitively expect that people who have been harmed would take great care to avoid further harm. In fact, the opposite is often true. As mentioned above, high risk sexual behavior is often seen following rape. Victims engage in repeated harmful behaviors such as self-cutting, suicide attempts and substance misuse. They sometimes expose themselves to the risk of harm e.g. by walking alone at night. The woman who has been raped is more likely to be raped again.

Re-traumatization assumes a further level of significance when trauma victims inflict harm on others. It is sometimes said that violence and traumatization behave like contagious diseases. In the words of W.H. Auden, 'Those to whom evil is done/Do evil in return'. There is now a substantial literature on the links between early traumatization and adult violence and criminality. In the words of one authority, people who have suffered trauma 'tend to lead traumatizing and traumatized lives...' [6].

The purpose of rape, sexual abuse and physical abuse is not just to inflict physical harm on the victim or to obtain sexual gratification. It is also to degrade and humiliate the victim [7]. The memories of humiliation are sometimes more searing than the physical pain. One way of dealing with this is what psychoanalysts call 'identification with the aggressor'. The victim deals with his humiliation by finding someone to victimize himself. He exchanges his humiliation for a sense of the dominance, power and control that he saw in the person who traumatized him. This may be accompanied by feelings of contempt for the weakness of these new victims.

Susan was quite a handful for those who tried to care for her. She was often violent towards carers and sometimes to other young people with whom she was living. When she attempted suicide by fire-raising, she seemed to have scant regard for the safety of others in the building.

\section{Reciprocity in Human Relationships}

A core characteristic of human beings is that we enter into cooperative relationships with each other. Our capacity to do this has been perhaps the main reason for our survival and our current dominant position in the ecosphere. This cooperation is achieved in part by systems of morality and social practices that determine our entitlements and the obligations that we have to each other.

One way in which we cooperate is by buying and selling goods and services in the marketplace. But money is a recent development on the scale of human history. The standard economic myth is that before we had money, we had barter. If I had more spearheads than I needed but lacked fish-hooks, I would find someone who had spare fish-hooks and who needed spearheads and we would then effect an exchange to our mutual benefit. Barter would obviously be a cumbersome and inefficient way for a group to organize its affairs. The reason is the obvious one that barter requires a 'double coincidence' of wants. It is highly unlikely that there will be someone who has spare fish-hooks and needs spear-heads at just the same time as I need fish hooks and have spear-heads to offer in exchange.

To overcome these problems, we invented money. This allowed an easier and more flexible system for the exchange of goods and services. And once we had money, we could create systems of credit and debt, along with banks, markets and financial services.

The reason I describe this as a myth is that there is no evidence anywhere in the world or at any time in human history of a society organized around barter. In fact, the standard economic account is completely back to front. Before we had money, we had credit and debt, not barter. If you needed spearheads and I had some to spare, I would give these to you. The debt would not be precisely quantified, but nevertheless, my gift would 
come with the expectation that you will reciprocate at something like the same level at some time in the future. At least, it comes with the expectation that you would reciprocate if the circumstances were to require this. Over time in a small-scale society, complex networks of mutual obligation are built up. Everyone is in debt to everyone else in a dozen different ways. In fact, social relationships are largely constituted by this (see Graeber [8] for a detailed account).

These debts need not be monetized or quantified but are nevertheless very powerful and are long -remembered.

The role of gifts in pre-state societies was the subject of some of the founding debates of anthropology and involved pioneers such as Marcel Mauss. He gave a detailed account of gift exchange in Pacific and North West Native American communities [9]. Social life, including relationships between tribes, clans and families, marriage, initiation ceremonies and social rank were all mediated by the giving, receiving and repayment of gifts. To give one example, '...gift-exchange pervades the whole economic life of the Trobriands. Social life is a constant give-and-take...' (ibid. 27).

There was a social obligation to receive gifts and, at some future time, to reciprocate with a gift of greater value. These gifts were not the ordinary items of consumption or utility. Instead, in the case of North West Native Americans, they were objects such as decorated coppers and embroidered blankets, which were considered to be sacred. The gift received did not come as a simple physical object. It also embodied something of the donor and served as a symbol of the obligation imposed by the donor on the recipient to reciprocate. In some cases, the gift was thought to have a 'spirit' that would inflict harm on a recipient who held on to it and did not reciprocate.

In modern societies, we hear echoes of these beliefs when we think about our attitudes and practices in relation to gifts. The distinction between selling an item of property to another person and a gift may be conceptualized as the 'inalienability' of a gift. If I sell something to someone, the ownership rights are transferred to the buyer and she can then do whatever she wishes with her purchase; in other words, the object is 'alienated' from the seller.

In the case of a gift, this alienation does not happen to the same extent. When I give something, I am not only giving an object. If I have given serious thought and prolonged deliberation to my choice of gift, I also give part of myself. One would usually be annoyed and upset to learn that the recipient had immediately passed the gift on to someone else or returned it to the shop, got the money back and spent it on something completely different.

This may also explain our sense that some things are too important to be bought and sold but can be given. Obvious examples are blood given for transfusion or organs for transplantation. Although it is possible in some places to sell one's blood or kidneys, most people feel uncomfortable with this and many societies prohibit these kinds of practices. It seems that some things are too precious ('the gift of life') to be subjected to commercial transaction but which can be given in a spirit of mutual aid.

In Maori communities in New Zealand there is a central concept of mana. This refers to the overall prestige or value accorded to members of the community, especially the rangatira or aristocracy. Mana is increased by a socially responsible life or memorable deeds. Mana can be lost as well as gained and is diminished by disregarding one's responsibilities or offending against the social norms of the community.

Relationships between individuals, families, communities and tribes were governed by a concept known as $u t u$, which is translated as reciprocity or balanced exchange. This ensured that relationships were governed by mutual obligation and an implicit keeping of social accounts. The bestowal of a favor increased the mana of the donor and required at some future time that the favor be returned by the recipient. The repeated exchange of favors and goods and the ensuing reciprocity could lead to social stability and mutual benefit.

In the same way, an insult or harm created an obligation to respond in kind. This might be a verbal insult, a territorial intrusion or direct harm such as the rape of a family member. In cases such as this, the only way to restore mana was by inflicting punishment on the perpetrators and a violent response was often obligatory.

This process of social accounting engaged considerable attention in Maori communities. If the balance of generosity or power was in your favor, your mana was enlarged. If you were in debit to your neighbors, your mana was diminished. Life was concerned not just with physical sustenance but also with levelling in your favour any perceived imbalance of $u t u[10]$.

Responding to wrong-doing by vengeful harm carries the risk of counter-retaliation and the triggering of prolonged conflict that eventually causes great damage to both parties. For this reason, the response to wrongful deeds has taken other forms.

Gift exchange has been used in many cultures in important transactions such as the arrangement of marriages 
and the settlement of disputes, especially those arising from personal injury or homicide. The gifts that are exchanged in these events are often of a standard form and have a value that is symbolic rather than practical. One example is wampum, beads made from shells, which were used for this purpose by the Iroquois tribes in North America. Their use following homicide was described by Lewis Henry Morgan in 1851, quoted in Graeber [8]:

Immediately on commission of a murder, the affair was taken up by the tribes to which the parties belonged, and strenuous efforts were made to effect a reconciliation, lest private retaliation should lead to disastrous consequences.

The first council ascertained whether the offender was willing to confess his crime, and to make atonement. If he was, the council immediately sent a belt of white wampum, in his name, to the other council, which contained a message to that effect. The latter then attempted to pacify the family of the deceased, and to induce them to accept the wampum as condonation...

The present of white wampum was not in the nature of a compensation for the life of the deceased, but of a regretful confession of the crime, with a petition for forgiveness. It was a peace offering, the acceptance of which was pressed by mutual friends...(p. 135)

A life that is lost cannot be restored and nothing else has comparable value. All that can be given is an honest acknowledgement that wrongful harm has been caused and a sincere attempt at reconciliation.

In modern societies, many of our interactions, especially those that take place in the context of close relationships, take place out with the money economy. If I invite you to my house for dinner, I won't end the evening by presenting you with a bill to cover the costs of the food that you have eaten and the wine that you have drunk. Nevertheless, you are still in my debt and what you owe me is reciprocity. I'll expect a return invitation some time in the future. Until I receive this, I probably won't invite you back a second time.

It's in this way, this giving and receiving of favors, that human relationships are created, maintained and strengthened. One could go further and argue that this is what most human relationships are. We enter into arrangements with other people with the aims of providing mutual aid and support. This only works for us if we keep some track of the costs and benefits that accrue. If you are my friend and I give you a thoughtful and expensive birthday gift but get nothing at all from you when my birthday comes around (for no good reason), this may be enough to end our friendship. The friend who seems always to be taking and never giving will eventually find that he is ostracized and lonely.

The opposite situation can arise when someone causes harm, for example by stealing and publishing one's ideas or writing an unfair and hostile review of a book one has written. In situations like this, the sense of grievance and resentment can fester for years.

The harm that is done is not only that you have been deprived of the benefits of your intellectual property. In the same way as a donor gives something of himself in addition to the physical object that comprises the gift, the theft of intellectual property can be seen as an assault on one's dignity and a breach of the respect to which we all feel entitled.

We pay constant attention to these issues, to this keeping of social balance sheets, to what we owe to others and what they owe to us. It has been said that much of morality comes down to the question, 'Who owes what to whom?'

Higher primates also exhibit behaviors that suggest that they have a sense of distributive fairness. Capuchin monkeys appear to be able to judge and respond to value. They can be trained to assign value to tokens and can use these tokens in simple barter transactions.

In one experiment, capuchin monkeys were paired with a mate from their group [11]. The monkeys were given a token which could be handed back immediately for a reward. Before each transaction, the monkey was able to see a similar transaction carried out with its mate and the reward received by the other monkey. Food rewards varied from items that were of low value to higher-value items, which the monkeys usually preferred.

The transactions were carried out in different conditions. In the first, an 'Equity Test', both monkeys were given the same low-value reward, such as a slice of cucumber. Although the reward was of low value, it sufficed to motivate exchange of the token. Secondly, an 'Inequity Test' was performed in which one monkey received a slice of cucumber and the partner received a higher-value reward in the same transaction. This took the form of a grape, which the monkeys always preferred to the cucumber. The third arrangement was an 'Effort Control' test in which the partner received a high value grape without having to surrender a token. 
In the 'inequity', situation, capuchins who received lower value rewards were less likely to complete the transaction or to accept the reward, compared to when both received identical rewards. Some refused to exchange the token or ignored the reward. Others responded more actively by protesting and throwing away the token or the reward. Refusal to cooperate was even more frequent in the 'Effort Control' scenario, when the partner was given the reward for nothing.

The theme of restoring balance has been a recurring theme in dramatic art from ancient Greece to the present day. From the plays of Aeschylus, to Shakespearean tragedies such as Hamlet and Macbeth, and just about every crime thriller since that time, we see the same dramatic arc. The story begins with an incident in which a serious wrong is inflicted on someone and proceeds through a series of twists and turns to resolution in the form of harm inflicted on the offender. It is this resolution, this restoration of balance, that gives satisfaction to the reader or viewer. The fact that we engage with this kind of cultural product most days of our lives points to how important this kind of narrative is to us.

It is commonly believed that the person who commits a wrongdoing has incurred a debt to the party who has been wronged. In German, the word for debt and guilt is the same - 'die Schuld'. The offender is often described as having incurred a debt to society.

One of our patients was a young soldier who had deployed to Afghanistan. He was suffering from posttraumatic stress disorder and one of the things that had traumatised him was the fact that he had accidentally shot and killed a young girl in the course of an engagement. The following day the girl's father brought her body to the camp to negotiate compensation. Every military base in Afghanistan kept a supply of US dollars to deal with eventualities such as this. The offence was acknowledged, a price was negotiated, the money handed over and the father left. The Army paid off its debt to the bereaved father and our young soldier was left to carry his burden of guilt.

The link between debt and sin is quite explicit in Christianity, Islam and other religious traditions. The Holy Quran 10.61 states that all our deeds, however small, are perceived by God and recorded in a clear register. In the Lord's Prayer, we find the line, 'Forgive us our debts as we forgive our debtors'. We often refer to Christ as the 'Redeemer'. The primary meaning of redemption is to buy something back or to recover something in exchange for payment or clearing a debt.
The central event in Christian theology is the crucifixion of Christ. To a Christian, this is the most important event in human history. The cross or the image of the crucified Christ is the central object of veneration for Christians. Why did Christ die on the cross? As most of us know, this was so that God could forgive our sins and we might be spared eternal damnation. But why? God is all-powerful and all-merciful. If he wished to forgive us, why not just do so and skip the gruesome and painful business of crucifixion? It seems that one thing that even almighty God cannot do is to waive the debt that is incurred by $\sin$ and wrong-doing. If forgiveness is to happen, a price must be paid.

There are two other notable features here. First, the payment of the debt in this way was not something that was forced on God or Jesus. Instead, it was a burden that was willingly assumed or, to put it another way, it was a gift bestowed on humanity.

Second, if we are all sinners and sin is a debt that must be paid off, then God is our creditor. We therefore have the situation of the creditor paying off the debt that is owed to him. Nietzsche [12] described this position as follows:

'...all of a sudden, we confront the paradoxical and horrifying expedient with which a martyred humanity found temporary relief, that stroke of genius of Christianity: God sacrificing himself for the guilt of human beings, God paying himself back with himself...'

I will not attempt any further theological interpretation of this or try to place it in the context of Nietzsche's argument. One approach in the philosophy of religion is to view religious belief and practice as expressions or symbols of human reality and this brings us back to my clinical case. When Susan Smith was raped, who paid the price? In the absence of justice, she paid it herself and ultimately, she paid with herself.

Victims of severe traumatization often treat themselves with horrifying cruelty. As a clinician, one commonly sees a malignant process that results in traumatised people covered in multiple, disfiguring scars and repeatedly endangering their lives with suicide attempts. The harms that they inflict on themselves often seem worse than the initial traumatizing event.

To conclude this section, the expectation and practice of reciprocity lie at the heart of human relationships. We seek always to restore and maintain balance in relation to other people. This applies both to favours and benefits 
and to insults and harms. This theme is a daily preoccupation. It is expressed repeatedly and insistently in the ways that humans have behaved throughout history and in narrative culture and religion. It arouses some of our most powerful passions and has provoked appalling violence. To many people, the principle of reciprocity lies at the heart of what they mean by justice. It also lies at the heart of human nature. Reciprocity makes the world go round.

\section{Reciprocity and Restoration}

What should this entail for our practices of criminal justice? One role of a system of punishment should be to be to provide ordered expression of the desire for justice, with the aim of preventing the contagion of suffering in the life of the victim.

The central tenet of restorative justice is to restore the victim of crime and the wider community of which she is a part to something as close as possible to how things were before the crime was committed. One authoritative account of restorative justice states that one of its roles 'should be restoration of the emotional or psychological state victims were in before the crime occurred' [13] (p. 33). The principal aim is reparation rather than punishment.

What has to be restored? Susan Smith endured a degrading, humiliating experience. Her personal boundaries were cruelly violated. She felt that her life and her body had been destroyed.

How do we repair the damage inflicted on someone like Susan Smith? One might say that she has suffered psychiatric injuries such as depression, post-traumatic stress disorder or borderline personality disorder and that she should be offered treatments appropriate to these.

A comparable situation might be a person who is badly injured in a road traffic accident that was caused by someone who was driving when intoxicated with alcohol. The person who caused the harm would be subjected to whatever legal process and sanction was appropriate. The victim would be offered any necessary medical help. The two processes would be separate and would not affect each other. The causes of the injuries suffered by the victim are not relevant to the nature or treatment of his injuries. These would be identical if he had caused the accident himself.

The situation is more complex when it comes to kinds of psychological injuries that I have been describing. The nature and severity of symptoms do depend very much on the causal circumstances. In particular, they depend on, and to some extent are constituted by, the fact that the causal event was an act of wrong-doing. In contrast with the injuries of road accident victim, psychological injuries cannot be separated from the moral conditions in which they have arisen.

Symptoms have to be understood in their causal context. The physiological hyperarousal that is a core symptom of PTSD can be described in terms, such as over-drive in the sympathetic nervous system and the creation of an enhanced 'fight or flight' response. But it also has to be understood as what happens when the world has changed from being a safe place to a frightening place. The survivor may be in a state of dread that the experience will be repeated. She faces a situation in which other people are threats until proven otherwise. It is what happens when someone is left feeling enraged at the harm that has been caused to her but helpless to do anything about this.

Another common reaction to this kind of trauma is depression. Again, one might say that depression is an illness like any other and that there are well-established treatments, such as antidepressants and various forms of psychotherapy. This is to ignore the meanings and quality that depression has when it is caused by severe traumatization and especially criminal wrong-doing. As already mentioned, there is the guilt of the victim blaming herself.

There is a sense that one has been violated and contaminated. One of my patients was a victim of sexual abuse. She showered several times each to try to restore a sense of cleanliness. She would sometimes scrub herself so hard that she bled.

A final cause of depression may be a sense that the moral order has been over-turned. We believe that good things happen to good people, that you reap what you sow and that bad people eventually get what is coming to them. People like Susan learn that bad things happen to good people and that people who cause serious harms often get away with it. Victims sometimes assume the burden of guilt themselves in order to sustain belief in a meaningful world $[14,15]$.

Susan felt guilty and ashamed about what had happened to her. She blamed herself. She had been warned by her mother not to walk alone on the path where she was raped and believed that she had been raped because she had disobeyed her mother.

She mortified her flesh with repeated self-cutting. She tried to burn herself to death on two occasions. If 
someone has decided to commit suicide, why choose such a painful and horrifying method? Why was the heretic burned at the stake?

The Bible tells us that the fate of sinners is hellfire and damnation. This happens after what is sometimes called the Day of Reckoning, another allusion to debt and moral accounting. The reason for hell-fire may be that burning for eternity is the worst punishment that humans can imagine.

There are also numerous references to fire as something that is pure and that can purify us and this may be relevant in someone who feels that she has been spoiled or contaminated by rape. In Exodus, the angel of the Lord appeared as a flame of fire in the burning bush. Luke Chapter 3, verse 16 reads as follows: 'John answered them all, saying, "I baptize you with water, but he who is mightier than I is coming, the strap of whose sandals I am not worthy to untie. He will baptize you with the Holy Spirit and with fire"'. Perhaps suicide by burning combined self-punishment and purification.

There are many studies of the long-term impact of trauma on victims. Unfortunately for the purposes of this paper, there appear to be no data on the question of whether perpetrators are apprehended and dealt with by the criminal justice system has any bearing on these outcomes.

There is compelling evidence that victims seek more than the punishment of offenders. One study in Germany [16] found that victims of crime were often left feeling harmed by criminal proceedings. Satisfaction with the outcome of proceedings was more strongly predictive of a good outcome for victims than severity of punishment. Also important to victims were information on the motives of the offender, admission of guilt and a request for forgiveness.

In 2016, the Alliance for Safety and Justice in the USA commissioned a survey of victims of crime in which their views were sought on what should be done to offenders. By large margins, victims believed that money should be invested in schools and education, job creation, crime prevention, drug treatment and mental health treatment rather than prisons. Most victims were of the view that sending people to prison made them more, rather than less, likely to commit crimes and that prison sentences should be shortened, and resources diverted to prevention and rehabilitation. They believed that criminals should be held to account in ways other than imprisonment e.g. rehabilitation and community service. They stated that prosecutors should take account of what victims believed would help them recover from the crime [17].
What does the demand of reciprocity entail when someone has been a victim of criminal harm? This is something more than commensurate harm inflicted on the perpetrator by a third party such as the criminal justice system. Reciprocal acts are usually carried out in the context of a relationship between the participating individuals and serve the purpose of regulating this relationship.

Antony Duff [18] has provided a critical examination of the concept of restoration that is relevant to this case. At heart, this is an attempt to restore the position of victims and society to where they were before the commission of the crime. This involves more than offering compensation for material loss. Someone who stole money or property could repair the damage that was done by returning the money or goods to their rightful owner.

In the case of criminal wrong-doing, there is a need to recognize not only that some form of damage has been done in the material sense. There is also a need to consider that the offender has caused damage to principles such as trust, concern and respect for persons that are essential to social harmony and co-existence. This entails recognition that a wrong has been committed as well as damage done. The wrong consists of a breach of the standards of conduct that are expected in a community.

The process of restorative justice involves some form of victim-offender mediation. This has two important consequences in the context of the present argument. The first is that the victim is brought into a relationship with the offender whose purpose is repair of the harm that has been caused. The second is that she is given an active role in deciding how to deal with the offender. This is the reverse of the powerlessness and humiliation that attend a crime such as rape.

The loss of a life is not something that can be compensated in any direct way. The same may apply to what is lost by a young woman who is raped. It may not be enough to admit the crime, express regret and seek forgiveness. It is essential in addition that something is given that has psychological or spiritual value to both donor and recipient. A second important point is the fact of something being given to the victim by the offender rather than extracted from the offender by a third party such as the criminal justice system. As with the exchange of gifts in other settings, the donor gives something of himself, for example a commitment to moral change. In contrast, the person who is punished in the usual way may be defiant, resentful and unrepentant and the victim may be well aware of this. 
According to Duff [18], the restorative process must include an apology from the offender. The three components of sincere apology are recognition, repentance and reconciliation. The offender must begin by recognizing that what he has done is wrong in the sense that he has violated the respect and concern that is owed to his fellow citizens. Repentance involves an acceptance of what a person has done, including an acceptance of responsibility, that one is apt for blame and that one is deserving of censure. It also requires repudiation of the action and a commitment not to repeat it. Repentance should be a painful process. One reason that it can be painful is that it is the result of censure of the offender by his fellow citizens. It requires acceptance of the fact that one has violated the rights of another person and a commitment to respecting these rights in the future. The process of recognition and repentance has the aim of reconciliation. The wrongdoer wishes to re-establish a relationship of mutual respect with his victim and his community in general.

Duff (ibid., 90-98) argues that this process requires something more than verbal apology. When someone does a good or bad deed of sufficient magnitude, recognition by other people takes a more tangible form. In the case of good deeds this might consist of financial reward, military medals or public honours. These offer public recognition of the good deed and have the effect of making the doer of good deeds feel good about herself.

The corresponding response to serious wrong-doing should be painful or burdensome to the wrong-doer. The burden of punishment serves to focus the attention of the offender on his wrong-doing. This may be done by means of direct recompense to the victim.

Duff (p. 82) has summarized this approach as 'restorative punishment and punitive restoration'. The difference from straightforward retribution is that the infliction of pain is not seen as intrinsically appropriate based on just deserts. Instead, it is an essential component of restoring the damage that has been done to the moral fabric of a community.

What can an offender give to a victim that would serve the conciliatory function served by wampum in Iroquois societies? A genuine apology accompanied by expressions of remorse and repentance may be of value. A commitment to make the world a better place and a practical plan for action to achieve this, which involves significant sacrifice on the part of the offender, may also help. The offender 'keeps promises' in restorative justice. In conventional justice, he 'follows orders'. There is evidence that it is more likely that promises will be kept than orders followed [13] (p. 58-60).

There may also be an imposition of some task or service to the community or a requirement to address the psychological motivations, such as the need to get money to fund a drug habit, which led to the offence. The aim of these measures is to restore the moral harm that has been done to the community. In doing something wrong, one has incurred a 'debt to society' and this must be repaid if normal relations are to be restored. A verbal apology, however sincere, is insufficient. The offender should experience some form of pain or burden that gives force to the apology and this should be proportionate to the wrongful harm that he has done. Punishment sends a message to the victim that acknowledges the seriousness of what has happened to her.

There have been several research projects in which offenders have been randomly assigned to restorative justice procedures as an alternative to criminal proceedings. When offenders are given the option of diversion from prosecution to a restorative justice procedure, they are more likely to acknowledge their guilt than those who are not given this option. In one study in Brooklyn, three out of four cases randomly assigned to prosecution as usual were never brought to justice. In contrast, $56 \%$ of cases assigned to the restorative option completed the process [13] (p. 68). The presence of the restorative option may allow action to be taken in people who might otherwise escape any consequence of their offence, for example as a result of the case being dismissed.

The facts that the majority of women who are raped do not, as in the case described in this paper, report the crime to the police and the low conviction rates in rape trials points to the greater need to lower the threshold for bringing cases to completion. One of the most distressing outcomes for victims is to have a case dismissed e.g. for lack of evidence. The restorative paradigm is one that will likely seem less intimidating to victims and for this reason may increase the likelihood that they will report the crime to the police.

There is good evidence for a positive impact of restorative procedures on recidivism in a range of offences and offenders. Restorative justice programmes seem to be more effective in reducing crime following offences that are more, rather than less, serious. It is more effective when crimes have personal victims and especially when these are crimes of violence [13] (p. 68-71).

Victims are usually pleased that they have participated. They report reduced feelings of fear and anger 
directed at the offender. They have better longer-term outcomes after restorative procedures than after criminal trials. They are less troubled by post-traumatic stress symptoms such as insomnia. They are able to return more quickly to work and other aspects of normal life. They are also less likely to seek violent revenge against the offender [13] (p. 62-65). As described above, the consequences of rape can include depression, selfblame, helplessness and distrust of others. To give victims a central role in proceedings in which they are supported by family members and a mediator may go some way to reversing these effects.

Restorative approaches to justice share some the features described in stateless societies such as the Iroquois. They engage the participation of people other than the offender and the victim. The commission of a crime is seen as something that must be resolved by the community of which both offender and victim are members.

\section{Conclusions}

In this paper, I have argued that reciprocity plays a central role in our social existence and in human relationships. This applies to beneficial actions and to those that cause harm. Both justice and morality have as a central concern the need to meet reciprocal obligations.

It is well-recognized that a range of harms can arise when someone is the victim of criminal wrong-doing. In many cases, we see victims feeling guilty about their victimization and punishing themselves by inflicting sometimes terrible damage.

In the case described, the perpetrators of the crime were never apprehended, charged, or punished. In consequence of this, the victim took upon herself the burden of guilt and punishment, culminating in her committing suicide.

A central role of any system of justice should be to improve outcomes for victims. It should especially ensure that it helps to prevent the kinds of horrifying outcomes seen in the young woman described above, where the harms caused by a victim to herself are worse than those arising from the criminal act.

There is good evidence that restorative justice procedures not only reduce recidivism but also improves outcomes for victims. In at least some cases, punishment of perpetrators may be a necessary part of restoring the harm caused to victims.
In psychiatric practice, we see many young people who have been traumatised by rape, sexual abuse and other criminal acts. I'll finish with two observations, one from personal experience and another on which there is general agreement. The first of these is that nearly all of the patients we see have been harmed by people who have not faced any form of censure such as criminal prosecution. The second is that these patients are very difficult to treat. Despite one's best efforts, one often has to deal with depression, suicide attempts, deliberate selfharm, eating disorders and other symptoms that last for years before some stability is reached. Perhaps the reason for this intractability is that what these patients need is something that no psychiatrist, psychologist or therapist can give them. Perhaps what they need is justice.

Open Access This article is distributed under the terms of the Creative Commons Attribution 4.0 International License (http:// creativecommons.org/licenses/by/4.0/), which permits unrestricted use, distribution, and reproduction in any medium, provided you give appropriate credit to the original author(s) and the source, provide a link to the Creative Commons license, and indicate if changes were made.

\section{References}

1. Walen, Alec, "Retributive Justice", The Stanford Encyclopedia of Philosophy (Winter 2016 Edition), Edward N. Zalta (ed.), URL = https://plato.stanford. edu/archives/win2016/entries/justice-retributive/.

2. Cauffman, Elizabeth, S. Shirley Feldman, Jill Waterman, and Hans Steiner. 1998. Posttraumatic stress disorder among female juvenile offenders. Journal of the American Academy of Child and Adolescent Psychiatry 37 (11): 1209-1216.

3. Clements, Paul T., Patricia M. Speck, Patricia A. Crane, and Martha J. Faulkner. 2005. Issues and dynamics of sexually assaulted adolescents and their families. International Journal of Mental Health Nursing 13: 267-274.

4. Sexual Violence Research Initiative. 2007. Rape: How women, the community and the health sector respond. Geneva: World Health Organization.

5. Tjaden, Patricia, and Nancy Thoennes. 2006. Extent, nature and consequences of rape victimization. Findings from the National Violence Against Women Survey. Washington: US Department of Justice.

6. van der Kolk, A. Bessel, and A.C. Alexander C McFarlane. 1996. The black hole of trauma. In Traumatic stress. The effects of overwhelming experience on mind, body and society, ed. B.S.A. van der Kolk, A.C. McFarlane, and L. Weisaeth, vol. 3-23, 11. New York: The Guilford Press.

7. Fiske, Alan P., and Taj S. Rai. Virtuous violence, 168-178. Cambridge: Cambridge University Press.

8. Graeber, David. 2012. Debt. The first 5,000 years. Brooklyn: Melville House. 
9. Mauss, Marcel. 1925, 2011. The gift. Forms and function of exchange in archaic societies. Mansfield Centre: Martino Publishing.

10. King, Michael. 2003. The penguin history of New Zealand. Auckland: Penguin Books.

11. De Waal, Frans. 2006. Morally evolved. Primate social instincts, human morality, and the rise and fall of "veneer theory". In Primates and philosophers. How morality evolved, ed. Stephen Macedo and Josiah Ober, 1-97. Princeton: Princeton University Press.

12. Nietzsche, Friedrich. 1887/2013. On the genealogy of morals. London: Penguin, 78.

13. Sherman, Lawrence W., and Heather Strang. 2007. Restorative justice: The evidence. London: The Smith Institute.

14. Janoff-Bulman, Ronnie, and Cynthia McPherson Frantz. 1997. The impact of trauma on meaning: From meaningless world to meaningful life. In The transformation of meaning in psychological therapies, ed. Mick Power and Chris R. Brewin. Chichester: Wiley.

15. Duckett, T. Simon. 2003. Surviving violent crime and the criminal injuries compensation authority. London: T.S. Duckett.

16. Orth, Uli. 2002. Secondary victimization of crime victims by criminal proceedings. Social Justice Research 15 (4): 313325.

17. Alliance for Safety and Justice. 2016. Crime Survivors Speak. The First-Ever National Survey of Victims' Views on Safety and Justice. https://www. allianceforsafetyandjustice.org/crimesurvivorsspeak/

18. Duff, Antony. 2002. Restorative punishment and punitive restoration. In Restorative justice and the law, ed. Lode Walgrave, 82-100. Uffculme: Willan Publishing. 